\title{
HOW CAN PUPILS SEE WHAT IS INVISIBLE?: POSSIBILITIES OF INQUIRY PROBEWARE EXPERIMENT IMPLEMENTATION IN PRIMARY SCHOOLS
}

\author{
W JAKI SPOSÓB UCZNIOWIE MOGĄ ZOBACZYĆ TO, CO JEST \\ NIEWIDZIALNE?: MOŻLIWOŚCI DOCIEKANIA PODCZAS REALIZACJI \\ EKSPERYMENTU W SZKOŁACH PODSTAWOWYCH
}

\begin{abstract}
We investigated the difficulties and challenges for teachers in implementing microcomputer-based laboratory and inquiry-based education in basic schools, where pupils were unused to this type of education. To achieve this, we implemented lesson models with worksheets focused on chemical reactions, chemical decomposition and chemical synthesis; with demonstration experiments and video-recording of each lesson. We then utilized a qualitative research design to analyse the videos, concentrating on circumstances leading to increased and decreased pupil attention to the relevant events, and on subsequent student reflection. Experience gained from implementing our model lessons proved that achieving effective teacher-pupil communication was the greatest difficulty hindering teaching success. This particularly involved the formulation of predictions and conclusions which demands strong commitment, determination and skill from every teacher. A further difficulty was ensuring active pupil engagement in the discussion. We therefore instituted a set of teacher 'working-rules' to enhance success in this innovative form of education.
\end{abstract}

Keywords: chemical reaction, demonstration experiment, inquiry-based science education, microcomputer-based laboratory, worksheets

\section{Introduction}

The promotion of a constructivist approach in education is a current trend in natural science didactics. This is based on pupil-oriented approaches, and was introduced to combat dissatisfaction with study results and the current state of natural science education where pupils show little interest in natural science and poor understanding of the important concepts involved [1]. In this context, the results of researches dealing with inquiry-based education connected with microcomputer-based laboratory (MBL) sound very interesting. Research results show that activity-based, computer-supported, interactive learning environments will better serve the needs of the diverse range of students studying science [1].

\footnotetext{
1 Department of Didactics in Science, Psychology and Pedagogy, Faculty of Natural Sciences, Comenius University in Bratislava, 84215 Bratislava 4, Slovakia, phone +421 260296451

* Corresponding author: vladimir.gasparik.347@gmail.com
} 
Constructivist use of MBL in chemistry teaching appears to further develop students' understanding of chemistry concepts and their meta-cognition. Further, Deng et al. [2] confirms that student meta-cognition is significantly associated with their conceptual understanding of chemistry. The key impact on the effectiveness of the computer-supported laboratory depends on the teaching method applied by the teacher and it is not normally advantageous to simply replace a traditional laboratory with an equivalent one using MBL. While the substitution is easy for schools to implement, a frequent result is that a simple laboratory is made more difficult and expensive by including computers without educational gain. Here, the MBL context adds capacity and flexibility that gives students greater opportunity to explore and learn through investigation, but it requires change in teaching style [3]. The effect is multiplied, as in the formula; "MBL tools $\mathrm{x}$ teaching methods", and it is obvious that when either factor is zero, the effect on education is zero, regardless of the other component's strength [4]. Teachers must find a suitable teaching method to ensure this teaching aid's success, and therefore it is highly recommended that theinquiry-based process predominates when the computer-based laboratory is introduced in science education. Computer-based experiments achieved positive learning outcomes when combined with inquiry-based education.

The basic mode of MBL operation involves one or more sensors connected to an interface and this to a computer. The interface is an analogue-digital converter and pertinent software programs the frequency of measurement with concurrent table/graph data presentation on the computer screen. This system measures magnitudes difficult to accomplish with traditional equipment, and the visualization provides real time experimental variables. Research has identified that the advantages of this technology extend beyond simply motivating students because, when adapted to science, it develops their ability to interpret graphs, and it can help to develop competencies and higher order learning skills in students. Students can use this technology to obtain data and the time-scale of data-capture can be very short compared to traditional equipment. This creates classroom-time to implement other activities including result discussion and interpretation and working with variables. Using this technology, predictions and hypothesis formulated by learners can have easy, rapid and precise feedback ratification [5]. The plotting of data in real time simultaneously with its acquisition enhances the students' understandings of the graphical representation of data. The tedium of gathering data in scientific experiments is removed and the time bonus lets students focus on the actual task at hand and develop true scientific methodology [6]. Research indicates that it is the real-time nature of MBL that accounts for the improvement in student achievement [7]. In other words, the effectiveness of the technique stems from the fact that the situation being examined by the student is actually occurring while the graphs relating to that event are being produced. Simple visual juxtaposition of event images and graphs is certainly not as powerful as seeing (and "feeling") the actual event as graphs are constructed. Real-time MBL experiments allow students to "see" and "feel" the connection between an event and its graphical representation [8]. The high $82.9 \%$ of teachers indicate that their pupils are able interpret graphs generated by MBL and most importantly, they can also explain them [9]. Immediate response to experimental work through a simultaneously drawn graph is extremely beneficial for students in both observed phenomena and process core understanding [7]. This is supported by many authors who have highlighted the advantages of simultaneously drawn graphs in making experimental results more obvious and clearer to pupils; and thus helping them to more easily understand experimental phenomena [10]. 
There are many researches dealing with the use of inquiry-based education and MBL in the teaching process [11]. We consider it of utmost importance to implement research results in specific lesson models in primary school practice. In particular, we have contributed to a specific proposal recommending introduction of these tools in our schools, because they will greatly enhance both teaching and learning.

Inquiry-based education is an inductive approach involving formation of general concepts based on previous experience with natural phenomena. The research topic "Chemical reaction" is considered a fundamental concept in the primary school chemical curriculum. Although pupils observe specific chemical reactions, they have problems in understanding them properly. For example, many experiments involve colourless reactants and products unobservable to the naked eye in solutions and gases, and therefore pupils are unable to directly observe changes in reactant and product amounts. Here, the computer-based laboratory supplies actual observation of chemical reaction results invisible to the naked eye and without any additional or over-complicated reasoning behind it. For instance, $\mathrm{O}_{2}$ and $\mathrm{CO}_{2}$ and relative humidity sensors allow observation of $\mathrm{O}_{2}$ consumption and $\mathrm{CO}_{2}$ and water production during ethanol combustion. Pupils thus gain sensory experience with substance consumption and production in this chemical reaction and can subsequently endeavour to create the reaction's conceptual content and then proceed to the inductive thought processes relevant in constructivist educational principles; from specifics to general/abstracts.

The results suggest that the unique advantages of MBL are underexploited in science learning because teachers generally lack the vision of how MBL can be used to enhance the student learning experience in inquiry-based science [12]. Therefore, insufficient teacher awareness of MBL's great potential and advantageous use and a lack of support materials is the major hindrance to MBL integration in the education process. These supports include sets of experiments appropriately incorporated in the curriculum, lesson models and worksheets. According to Sorgo and Kocijancic [13] and Bingimlas [14], teachers face many difficulties that deter them from using MBL experiments.

\section{Objectives}

Our work assessed the possibilities of inquiry-based and microcomputer-based experiment implementation in primary schools. To achieve this, we created two lesson models on the topic "Chemical Reaction" using MBL and inquiry-based education. Inquiry-based lab worksheets were included in the lesson models, which focused on the following terms: "chemical reaction, chemical decomposition and chemical synthesis". These topics are introduced in the $7^{\text {th }}$ grade curriculum, when pupils first begin chemistry studies, and our task here dealt with verifying implementation possibilities in Slovak Republic primary schools. We were especially interested in how pupils would react to this novel mode of teaching and the extent of their cooperation with the teacher, and also if students were well-motivated by inquiry-based lessons and how easily they were able to solve resultant questions. We therefore monitored the difficulties faced by the teacher during these lessons and the circumstances supporting successful learning and active pupil discussion. These investigations led to formulation of suggested 'rules' to be implemented in teaching this type of lesson. 
We established the following aims:

1. to recognise and precisely comprehend the reasons behind pupil reaction to inquiry-based and microcomputer-based lessons; in terms of motivation, concentration and active discussion;

2. to identify difficulties the teacher encounters in applying the model lessons;

To achieve these first two aims we created lesson models focused on chemical reactions, chemical decomposition and chemical synthesis using MBL and inquiry-based education. The models were then open to modification, dependent on experience acquired in delivering the lessons.

3. to propose rules which ensure successful application of these models, and rules the teacher should employ in the subsequent verification phase.

This article forms part of a larger study concerning inquiry-based and microcomputer-based chemical experiments for primary schools.

\section{Method}

Lesson models and worksheets were tested in the 7th grade (pupils aged 12-13) of one primary school in Bratislava. There were 20 pupils (11 boys, 9 girls) and 19 (12 boys, 7 girls) in two classes involved in our research in the 2014/2015 school year. Overall, all pupils lacked experience in doing experiments, and had witnessed only one MBL demonstration.

Video recordings were made of each lesson. We initially placed unplugged video-cameras in the classroom to accustom pupils to their presence, so they paid no further attention to them. We then recorded the entire two lessons using four videocameras; focusing on different parts of the room to record all students. All videotapes were transcribed within hours to a few days of recording.

Our assessment and evaluation method is "design-based research" where we utilized a qualitative research design to analyse videos; because this approach offered great opportunity to further optimize lesson models and pupil worksheets if necessary and also teacher lesson organisation. We concentrated mainly on videotapes analysis, but complement our data with pupils' completed worksheets and transcripts of non-structured pupil interviews. We incorporated elements of the "grounded theory" method with opened and axial encoding [15]. During video analysis, we determined circumstances leading to increased pupil attention to the relevant events and their reflections, and thus their understanding of the process and concepts. We also noted circumstances surrounding decreased pupil attention to these factors and consequent inhibition of desired understanding.

Table 1

Lesson models and corresponding topics and concepts

\begin{tabular}{|c|c|c|c|}
\hline $\begin{array}{c}\text { Number } \\
\text { of model }\end{array}$ & Topic & Taught concepts & $\begin{array}{c}\text { Number } \\
\text { of lessons }\end{array}$ \\
\hline 1 & Chemical reactions & $\begin{array}{c}\text { reactant, product, consumption, } \\
\text { production, chemical reaction }\end{array}$ & 1 \\
\hline 2 & $\begin{array}{c}\text { Chemical decay and chemical } \\
\text { synthesis }\end{array}$ & catalyst, chemical decay, chemical \\
synthesis & 1 \\
\hline
\end{tabular}


Our first lesson demonstrated the term "Chemical Reaction" in an ethanol combustion experiment and the second focused on the concepts of "Chemical Decomposition" and "Chemical Synthesis' in the decomposition of hydrogen peroxide and magnesium burning. Two lesson models and corresponding topics are listed in Table 1.

The students should already have acquired basic chemistry knowledge from previous lessons, including; (1) the definition of chemistry as a science (2) substances and transformations between substances; (3) the difference between a pure substance and a mixture and (4) basic knowledge of water, oxygen and carbon dioxide. Prior to the Chemical Reaction topic, pupils learn the difference between physical and chemical processes; where the chemical process is defined as "the process where substances are changed into different substances".

Banchi and Bell's [16] structured inquiry was adopted in our lesson model creation and this is reflected in the structure of the inquiry-based laboratory worksheets (Fig. 1). Inquiry-based education consumes greater time than traditional instruction lesson, so we preferred worksheets use rather than note-taking. The worksheets contain diagrams of completed apparatus and form a pre-printed part of student notes; so pupils only need to complete the text. Thus, we retain time for the experiment itself and also reflection and the most important follow-up discussion.

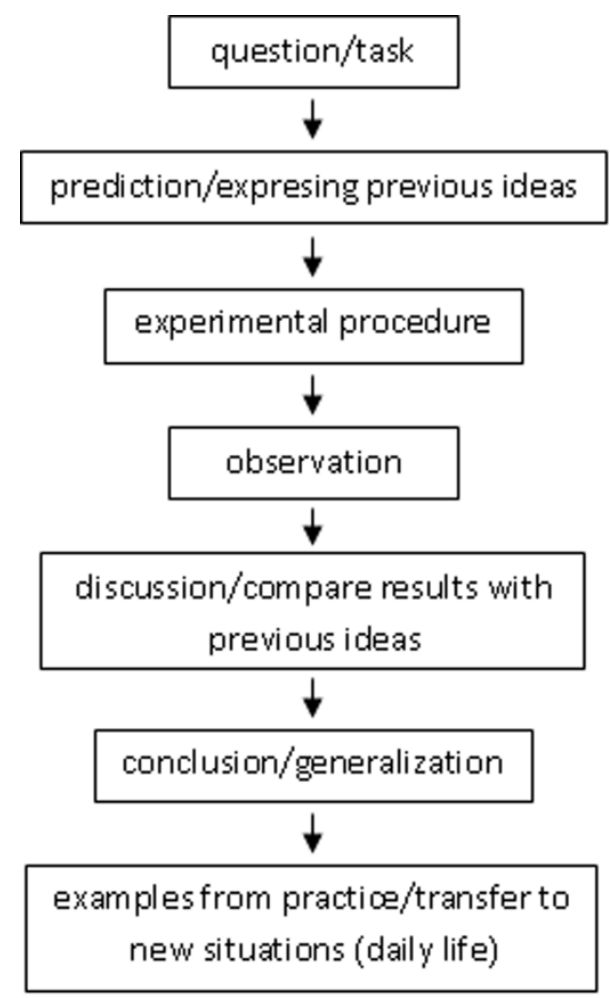

Fig. 1. General inquiry-based framework for MBL activities 
The MBL experiments in our lesson models are demonstration experiments. This approach solves two potential key problems which arise in MBL experiments. The first involves the high price of using sensors and consequent low possibility of affording more than one set for a class, and the second acknowledges that pupils have insufficient experience with MBL. Although it may initially appear that demonstrations do not conform with constructivist principles, demonstrations combined with inquiry-based education provide considerable benefits. Banchi and Bell [16] describe different levels of inquiry-based education giving examples of experiments used as demonstrations, and principles of adequacy and progression confirm the appropriateness of conducting these experiments as demonstrations. The performance of our experiments is relatively demanding and the pupils see experimental data recorded in a graph for the first time.

\section{Description of chemical experiments}

In the first lesson on Chemical Reaction concepts, pupils observe ethanol combustion. Burning is performed in a glass tank with sensors for $\mathrm{O}_{2}, \mathrm{CO}_{2}$ and relative air humidity (Fig. 2). The base consists of polystyrene wrapped in aluminium foil with grooves cut for sensor wiring; and a small piece of aluminium foil is placed between the watch glass and sensors to prevent fire. In addition a small piece of cotton-wool is applied to the $\mathrm{O}_{2}$ sensor to off-set condensation humidity and smoke and a piece of rougher aluminium foil is fixed at the inner bottom of the glass tank to protect the glass from fire. The teacher pours a $2 \mathrm{~cm}$ diameter quantity of ethanol into a watch glass. This will be consumed in the reaction when the teacher commences data measurement and ignites the ethanol. A dark background is most suitable for this demonstration because the combustion has little luminosity.

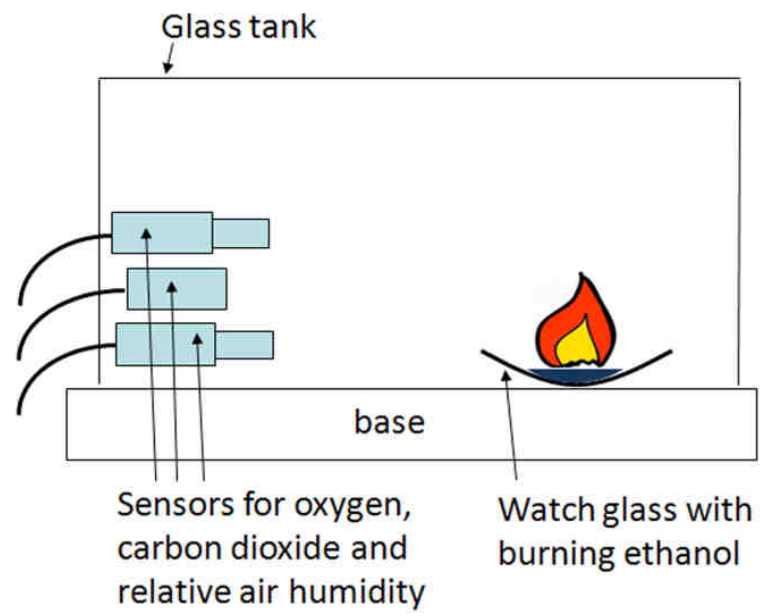

Fig. 2. Apparatus for ethanol combustion

During combustion pupils observe that ethanol burns out and the glass becomes hazy. They also observe experimental values changing on the computer screen and simultaneous generation of the graph describing gas amount dependence on time (Fig. 3). Measured experimental data is screened via data projector. The chemical reaction is as follows:

$$
\mathrm{CH}_{3} \mathrm{CH}_{2} \mathrm{OH}+3 \mathrm{O}_{2} \rightarrow 2 \mathrm{CO}_{2}+3 \mathrm{H}_{2} \mathrm{O}
$$


a)

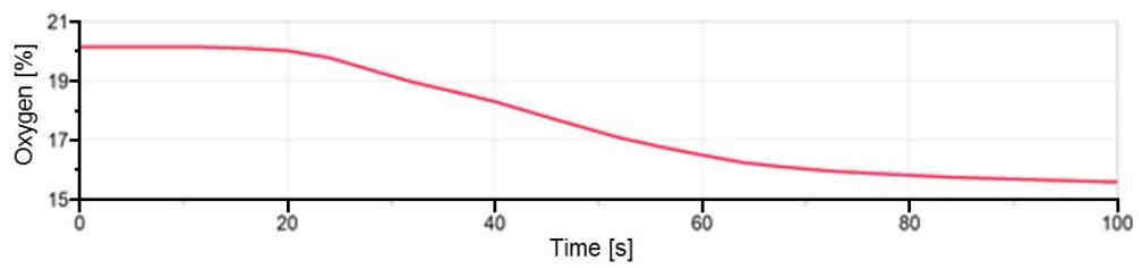

b)

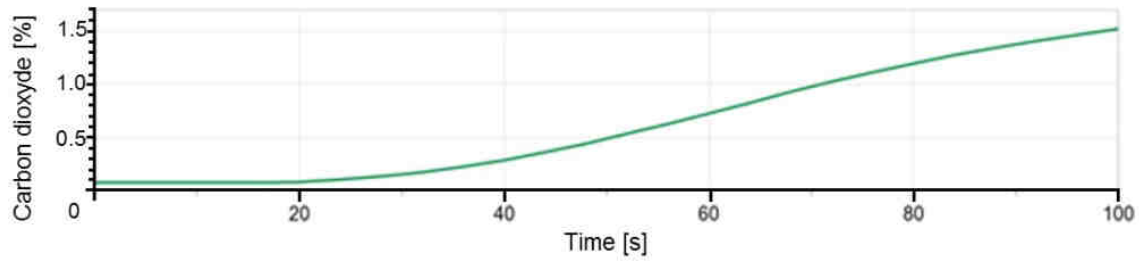

c)

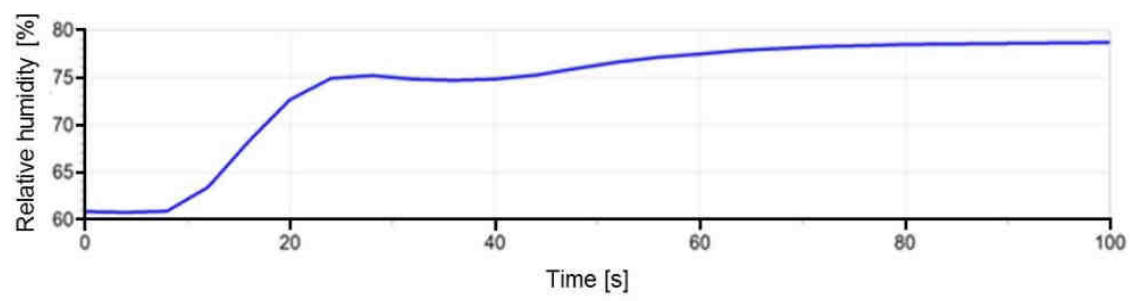

Fig. 3. Dependence of amounts of: a) oxygen, b) carbon dioxide and c) air relative humidity on time

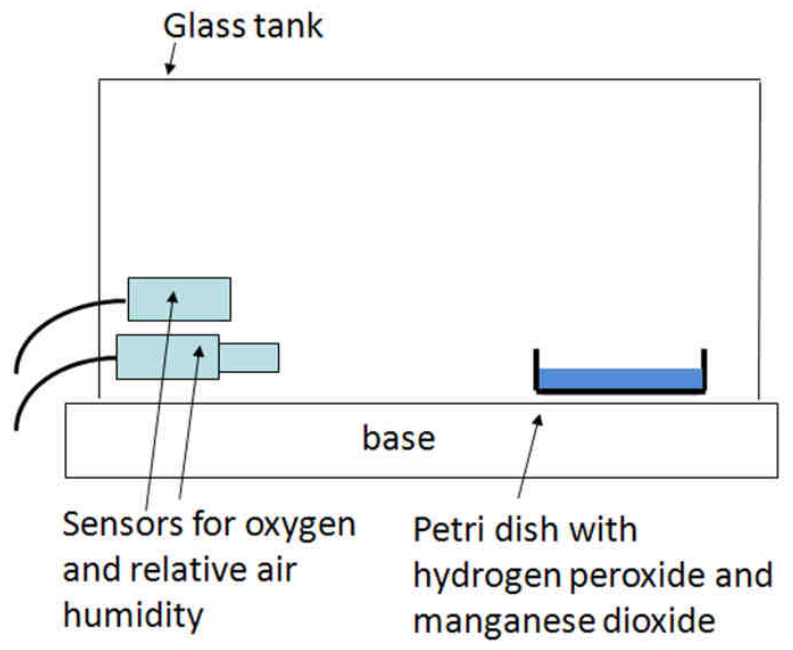

Fig. 4. Apparatus for hydrogen peroxide decomposition 
In the second lesson on Chemical Decomposition and Chemical Synthesis concepts, pupils observe two experiments. The first is decomposition of hydrogen peroxide catalyzed by manganese dioxide. In this experiment we use sensors for $\mathrm{O}_{2}$ and relative air humidity (Fig. 4). A small piece of aluminium foil is placed between the Petri dish and the sensors to save them from mixture sparkling. There is $30 \mathrm{~cm}^{3}$ of hydrogen peroxide diluted with water in proportion 1:3 in the Petri dish. The teacher starts data measurement, adds a small amount of manganese dioxide to the Petri dish, and covers it with the glass tank.

Here, pupils observe how mist and bubbles form during decomposition. They should also see that no manganese dioxide was consumed. If pupils are unsure whether the manganese dioxide was consumed or not, the teacher can repeat the experiment; weighing manganese dioxide before and after the reaction. The computer screen displays the simultaneously drawn graph (Fig. 5). The chemical reaction proceeds as in the following equation:

$$
2 \mathrm{H}_{2} \mathrm{O}_{2} \rightarrow \mathrm{O}_{2}+2 \mathrm{H}_{2} \mathrm{O}
$$

a)

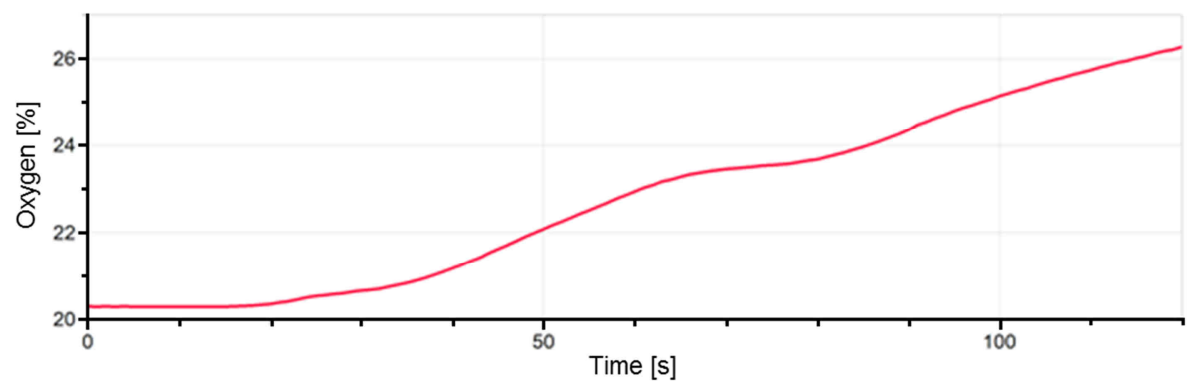

b)

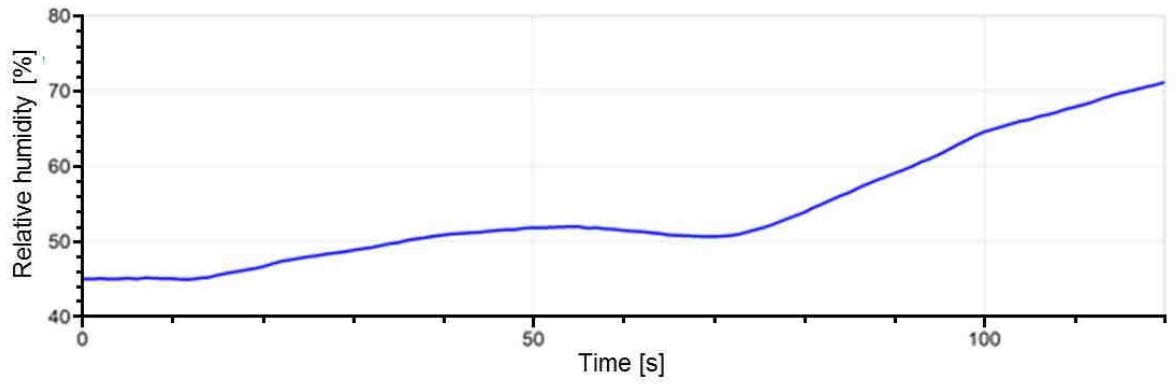

Fig. 5. Dependence of amount of: a) oxygen and b) air relative humidity on time

The second experiment involves magnesium combustion. Here, we use the oxygen sensors shown in Figure 6. The reaction is performed in a small iron dish inserted in sand, and a small piece of aluminium foil is placed between the iron dish and the sensor to save it from smoke. The teacher starts data measurement, then takes a small piece of magnesium in iron tongs and ignites it by gas-burner. When the magnesium ignites, the teacher quickly transfers it to the iron dish and covers it with a glass tank. 


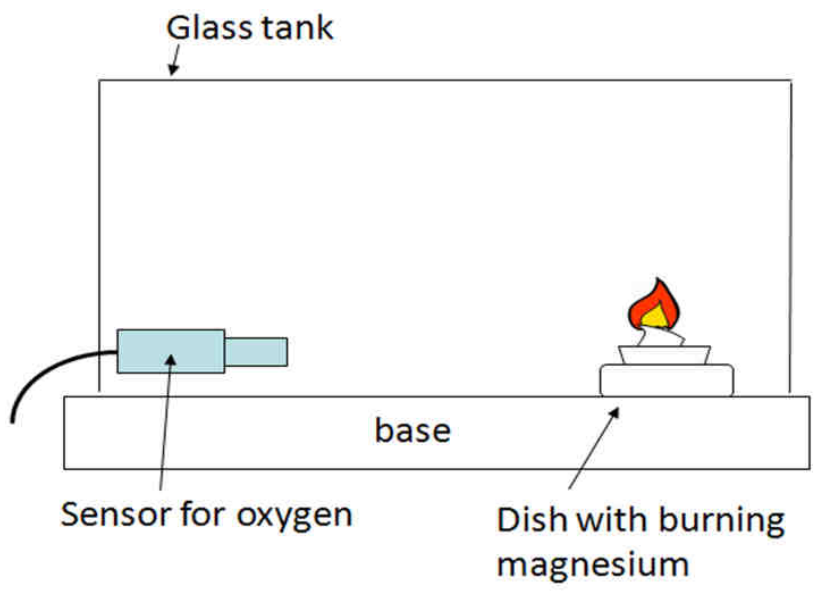

Fig- 6. Apparatus for magnesium burning

During magnesium burning, pupils can observe white smoke and magnesium transformation to white powder. They also see a simultaneous graph being generated on the screen (Fig. 7). The Chemical Reaction proceeds according to equation:

$$
2 \mathrm{Mg}+\mathrm{O}_{2} \rightarrow 2 \mathrm{MgO}
$$

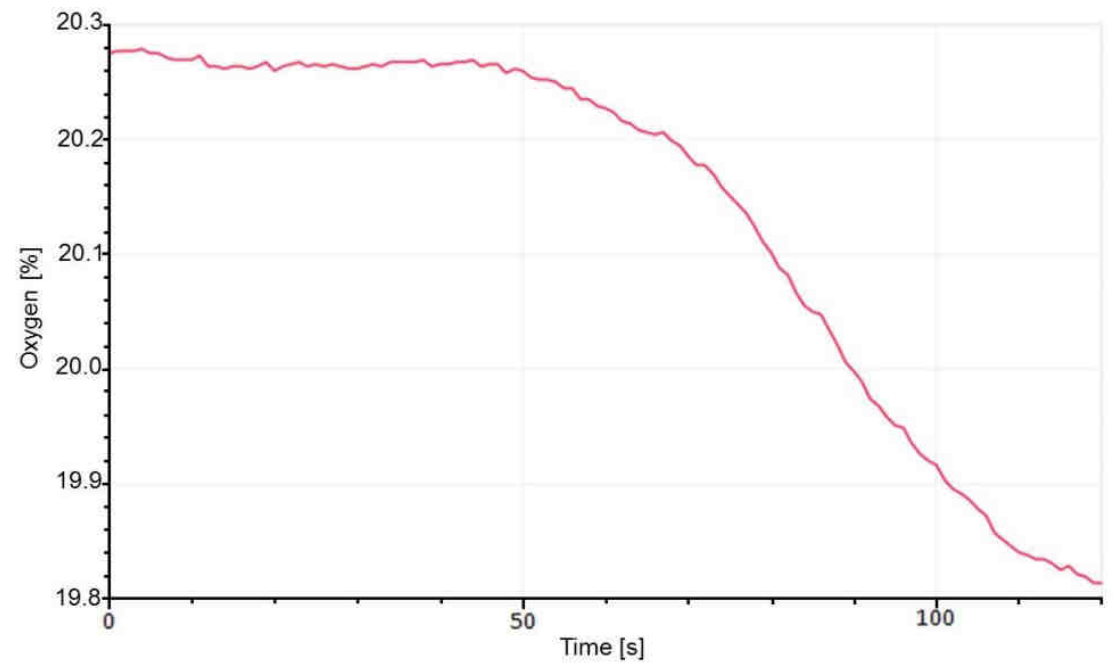

Fig. 7. Dependence of oxygen amount on time

\section{Instituted model - first lesson}

In this article we show model of the first lesson.

The lesson model is designed within the general inquiry-based framework for MBL activities (scheme No. 1). The first lesson deals with the concept "Chemical Reaction". Pupils also learn the following terms: 'reactants' and 'products'. The lesson commences 
with a task assignment written by the pupils in their worksheets. Then, the teacher asks pupils to brainstorm their ideas on chemical reaction.

Task: Define a chemical reaction.

Question: What do you think a chemical reaction is?

The teacher summarizes pupils' ideas from the discussion in concise completed form, and pupils write the following assumption in their worksheets.

Prediction: The pupils' ideas of chemical reaction formulated by the teacher.

The teacher suggests a procedure to examine what chemical reaction is.

Procedure: We will examine the chemical reaction of alcohol burning.

The chemical reaction is initially demonstrated without MBL. This is done because chemical reactions trigger a very strong reaction in pupils when they see them for the first time; -almost magical- so it is almost impossible for some students to focus on both the action taking place and the thought processes required to define 'Chemical Reaction'. Following this initial demonstration without MBL, the teacher emphasises the importance of further examining the reaction with sensors. The procedure, apparatus and diagram with its description are in pupil worksheets; thus saving important lesson time.

The teacher then demonstrates the experiment with MBL. When the flame extinguishes, it is necessary to wait a short time to accommodate the time-delay in gas sensors response. When the sensors record the gas values, pupils describe their observations in a follow-up discussion with the teacher and record their final observations.

Observation: The glass became hazy, alcohol was burnt out, the amount of oxygen decreased, the amount of carbon dioxide and water increased.

During the discussion, the teacher asks a series of questions. Pupils create contents of the concept of chemical reaction step by step by answering every question, and answers are written in their worksheets.

Discussion: What substances were consumed? What substances were produced? What happened with the substances that were consumed? Why were they consumed? Where do the produced substances come from?

It is suitable to show pupils the related graphs at the same time of using the terms "production" and "consumption" by the teacher.

Expected answer to the third and fourth questions above is;

What happened with the substances that were consumed? Why were they consumed? They were transformed into different substances.

If pupils are unable to answer these, they can try to answer the question: What are the substances produced from? Then they turn back to the previous questions. Expected answer: Where do the produced substances come from? They arise from conversion of the consumed substances.

Chemical Reaction ideas are summarized by pupils in a scheme pre-printed in the worksheet as two empty bubbles: 


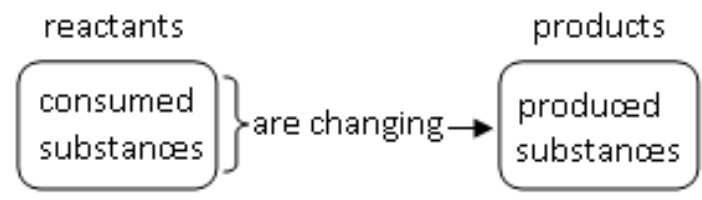

At the end the teacher reminds pupils of their former ideas about chemical reactions and altogether they adjust and complete them based on the collected findings. The teacher then asks pupils to define the term 'Chemical Reaction'. Pupils write this definition in their worksheets.

The conclusion: According to the discussion with pupils the teacher formulates the definition of chemical reaction. For example: Chemical reaction is a process when chemical substances are changed into different ones. It is a process when some substances are consumed because they are transformed to different substances which are produced.

Then, reactants are defined as substances which are consumed and products are the substances produced. Pupils write this definition into the scheme above. The teacher then tasks pupils to formulate the definition 'Chemical Reaction' using the terms 'reactants' and 'products'.

Completion of the conclusion: Reactants are changed into products in the chemical reaction.

In the "prediction" part of the lesson, pupils often express the idea that a chemical reaction is the answer of one substance to another one. However, a mere contact of alcohol with oxygen is not sufficient to start the reaction. To verify this prediction, we conduct the additional experiment of sodium reacting with water. Although results show the prediction was correct, it have to be complemented. Some chemical reactions start spontaneously, such as the reaction of sodium with water. On the other hand, in some chemical reactions (e.g. alcohol combustion), only a mere contact of the two substances is insufficient to start the reaction, and must be triggered by prior addition of energy.

The teacher asks the pupils to think about the abovementioned conclusions and compare them to results from their observation of the reaction of sodium with water. life.

Finally, the teacher and pupils search for examples of chemical reactions in everyday

Examples: burning, breathing, digestion, photosynthesis, cooking and decay.

\section{Results}

\section{Experience gained from implementing our model lessons}

When we analysed the lesson video recordings, we determined which circumstances led to maintaining our pupil's attention on the relevant events, thoughts and understanding of the activities and terms, and which circumstances failed in this regard.

\section{Behaviour of pupils during observation of chemical reactions}

On entering the classroom, the pupils immediately saw chemicals and instruments on the teacher's table and they guessed that they would see experiments. Most pupils reacted 
enthusiastically, with lots of Joyful shouts and comments, including; "We will do abracadabra" and "Hooray, we'll do our own chemical experiments, wow."

The subsequent chemical reaction processes held the attention of all pupils, and they were impressed by what they saw; regardless whether the experiments had MBL or not. However, differences were noted in the pupil's behaviour; where experiments without MBL were more often accompanied by appreciative shouts while the MBL chemical reaction processes were observed more quietly. These prompted student questions, such as: "What is the temperature inside (the apparatus)?" and statements like: "Oxygen is coming slowly". During the hydrogen peroxide decomposition experiment, the pupils' statements and ability to interpret graph formation is recounted in the following teacher-pupil communication transcript.

P4: We would not choke there.

$\mathrm{T}$ : What is formed there?

P16: Oxygen.

T: Oxygen is formed.

P16: We would not choke, because oxygen increases.

$\mathrm{T}$ : Yes, oxygen is formed and what else happens?

P7: Water increases.

Thus, observation of our chemical reactions with MBL proved very attractive for pupils, and simultaneously evoked comments and discussion of the observed phenomena. This interactive experiment confirms results recorded in previous MBL and inquiry-based approaches to natural science didactics.

\section{Teacher-pupil communication}

Sustaining pupil attention and active engagement is paramount for their comprehension and assimilation of new terms, and therefore ongoing contact between teacher and pupils by asking questions and raising challenges is a key aspect of successful teaching. The formulation of predictions, observations, discussion and conclusions are most significant chemistry education outcomes, and these require precise teacher/pupil communication.

Our video-recording analysis provided the teacher-pupil discussion transcript. It highlighted pupils' responses and the difficulties the teacher must overcome in MBL inquiry lessons.

\section{Pupil engagement in discussion}

The teachers' questions were mostly answered by pupils in the first row, so the discussion was often led by the teacher and these most active pupils; with other pupils' opinions rarely being sought. The remaining pupils relied on the most-active 4-5 pupils' for teacher-pupil interaction and thus, the achieved answers and interpretations were not the product of 'whole-class thinking'. Our ethanol-burning experiment was conducted and then thoroughly discussed. Here, pupil engagement in discussion is demonstrated in the transcript extract on: "Reactants are changing to products".

T: What happened to the matters consumed? Where did they go?

P2: Burned out. They were consumed by burning.

T: What does it mean "burned out"?

P2: They died, were consumed, were changed to carbon dioxide and water. 
Pupil No. 2 then formulated the idea that matter consumed is changed to matter produced. Here, the teacher wanted to engage more pupils in the discussion, besides that one active pupil, so he repeated the question.

T: The matters disappeared, but can not go to nothingness. Can something only disappear?- and nothing remain after it?

P2: Yes, a black hole.

P4: It can.

P2: Black hole?

P4: But, always something remains.

T: Why did the matters disappear, what happened to them?

P2: They changed; oxygen to carbon dioxide and ethanol to heat.

Once again, only the most active pupils responded and were engaged in the discussion.

The teacher invited others to share their opinion, and he offered a "helping-question".

T: What about all you other pupils, please try to answer the questions too.

T: So, I ask you again. Where do these matters that are produced come from?

P9: In the chemical reaction?

T: Yes, you are right; they arise in the chemical reaction. But what from?

P3: From the matters that were consumed.

However, pupils number 3 and 9 are amongst the most active ones, therefore the teacher repeats his question hoping other pupils will join the discussion.

T: They came from the matters that were consumed? So what happened to these matters that were consumed?

P2: They changed. (P2=Peter)

T: Please let other students answer, Peter. - So, what happened to the matters that were consumed?

P3: They changed to products.

T: To what substances were they changed?

P4: To carbon dioxide and water.

T: Yes, so we have matters consumed and matters produced. So, why were matters consumed? What happened to them? I am asking all of you, not only the pupils right here in front of me.

(After a few seconds of waiting)

T: I am not giving you the answer. I am still waiting.

T: So; I will try to ask the same question in a different way. There are some matters produced; these matters appeared. What did they come from?

Once more, only the most active pupils, pupils No. 2, 3, 4, and 9, held up their hands, and all the other students remained passive.

In the discussion, the main idea "reactants are changed to products" was mentioned only by the most active pupils while the others did not confirm or deny this comment. The teacher wanted the other pupils to join in, but he did not just want pupils passively nodding their heads, so he did not ask the obvious simple question; "What do other pupils say, do you agree with what the front row said". Instead, he kept formulating the same question in different ways, trying to encourage other pupils to respond.

Similarly, only some pupils in the second class joined in the discussion, but the teacher was satisfied with this result and did not pursue other pupils to participate. 


\section{The teacher's monologue}

Pupils lose concentration on important phenomena and ideas when the teacher monologue is too long; more than one minute. Pupils get bored or their attention is easily diverted to surrounding classroom events. One example occurred when the teacher was explaining the necessity for examining the ethanol-burning chemical reaction combined with sensors. This required a monologue where some pupil's attention wandered. Here, the teacher could have altered his approach by asking questions; such as: "What substance is also necessary for combustion?" "Could we see what happens with oxygen?". Here, asking questions and posing tasks proved important factors in invoking and maintaining pupils' attention.

\section{Teacher response to pupil ideas}

The teacher should comment on each pupil's ideas, and relevant comments should then be clearly formulated and integrated in final class results. When irrelevant or incorrect ideas are given, these should be eliminated by appropriate questions and reactions. The following video-recording transcript exemplifies a teacher request for pupil predictions (What do you think a chemical reaction is?):

P1: "We have two reactants, and the reaction goes on to give products."

P2: "What happens, if we join two different substances ..."

...

T: "So, are you all familiar with the meaning of the terms reactant and product?"

P1: "I am the only one who knows it."

T: "I see! Ok! What about the rest of the class? What do you think?"

$\cdots$

P3: "A change that happens in chemistry".

...

T: "So! Now I think it's best if we look closely at some chemical reaction. Then we will try to define the term chemical reaction again".

The teacher assessed the situation; concluded that pupils were unable to express any ideas about Chemical Reaction on their own, and continued without formulating a prediction. It was correct that a prediction was not formulated according to pupil No. 1, because it was evident he knew more than his classmates. Any prediction would therefore not reflect the ideas of the whole class. At the same time, the teacher overlooked the fact that pupil No. 2 expressed an idea which could have been used as the basis to formulate a relevant prediction. In addition, the statement made by pupil No. 3 could have been responded to by questions: "Do chemical reactions only take place in chemistry? What is changing there?"

The pupils' most frequent relevant statements about chemical reactions can be divided into two groups.

The first group is formed by ideas, such as: A chemical reaction is an "Answer to the impulse of two or more substances." "Reaction on the impulse of one object to another one.", "When we put two substances together", "Reaction to some different substance.", "Some chemical phenomenon when some object answers to some substance". "What will happen, when something is joined, maybe two different substances?" The teacher should guide pupils by appropriate questions, such as: "What do you mean by the word impulse?" 
"Are objects also composed of substances?" Then, the teacher can generalize those predictions as: Chemical Reaction; "It is the result of contact between two substances."

The second group contains the following statements: "It is some phenomenon when something changes in a substance"; "The whole substance can change"; "It is a change which occurs in chemistry"; These ideas can be generalized as: A chemical reaction is an "Action when substances are changed."

Although teacher/pupil communication can be quite difficult for the teacher especially in the formulation of predictions and conclusions (generalisation), the teacher must not be discouraged by early failures. A tremendous lot of hard work, experience, self-reflection and practice are required for every teacher to manage these situations.

\section{Interpretation of measured data}

Chemical reaction changes in gas amounts were simultaneously recorded and displayed by data-projector. Both graphs and numerical gas amounts were shown on the screen. So, we are now able to check how intuitive pupils are in interpreting graphical recordings. When using MBL, the teacher only explained that the screen showed both gas amount values and the changes in these amounts illustrated on a graph; without giving a detailed description of the screen display. Pupils intuitively understood the graphical representation of substance amounts as the chemical reaction proceeded. This is obvious in the pupils' comments: "Air humidity is rising. Oxygen does not change, oxygen goes down". This pupil's observation that "oxygen does not change" was related to postponed oxygen sensor reaction; a normal parameter in gas sensors. Consequently, pupils had no problem interpreting data and they were able to intuitively evaluate progressive increases and decreases during the chemical reaction. Our finding agrees with previous research reports [9], and this approach negated lengthy detailed explanation of graphs depicting the dependence of gas changes on time. It was sufficient here for the teacher merely to reinforce pupils that they had directly observed the gas amount changes recorded both numerically and on the graph.

\section{Class organisation}

The pupils in the back rows were asked to come closer so they could see the experiment properly. Unfortunately, prior to the demonstration, the teacher had not adequately considered how to deploy pupils around the teacher's desk. This led to crowding, pupils blocking each other's view, distracting each other and also shading the view of the experiment. This resulted in some students getting bored; and standing for long periods was also uncomfortable and distracting for some pupils.

\section{Pupils' concentration}

We noted which circumstances led to improved pupil concentration on discussion and teacher activities, and which decreased it. For example, the above mentioned teacher monologue and constant pupil movement to clearly observe the demonstration in small, badly deployed areas clearly distracted the pupils' attention. However, even when observation was not obscured, the mere act of being so close together, and often in contact, caused some pupils to engage in behaviour unconnected with education, and others to concentrate more on their worksheets than pay attention to the experiment and contribute to the discussion. 
However, overall, our chemistry demonstrations were so new and interesting that most pupil attention was captured, and the posed questions and set tasks increased and maintained attention levels.

\section{Conversation between teacher and pupils at the end of the lesson}

At the end of the lesson, the teacher told pupils to learn all the subject matter they correctly note in the discussion any conclusions parts of the worksheet. This was well received by the pupils'; with reactions such as: "Oh, that's good", and also some positive non-verbal expressions. Pupils were surprised and happy they could learn information they formulated themselves, and thus felt they were an active part of the education process, rather than just passive acceptors of traditional education.

The teacher therefore questioned pupil reactions:

T: How do you like this lesson?

Pupils' responses:

"I like it. Every lesson should be like this. Will we do experiments each lesson? It was good. It was very interesting and better than our normal lessons. Finally we saw something in practice. Better than previous lessons. Next time, will we have the same?"

T: Would you like more lessons like this?

P: Yes.

T: We will continue next time.

P: Great. What magic will we have next time?

Some pupils were so inspired by the lesson that after this class they discussed some aspects of the experiments with the teacher, wanting more information, so the teacher referred them to simple web-sites about experiments and especially the use of sensors.

\section{Discussion and suggestions}

First aim of our work was to obtain pupils' responses to this way of doing lessons from point of view their motivation, concentration and active engagement to discussion.

\section{Pupil motivation}

Pupil motivation was evaluated on written responses while observing the chemical reactions, their participation in discussion and on pupil interviews conducted at the end of each lesson. Our results confirmed that the pupils looked forward to lessons with experiments and paid close attention throughout the experiment, regardless whether MBL was used or not.

In end-of-lesson non-structured interviews, pupils indicated they wanted these lessons more often because: "They are different and more interesting than what we had before" and "Finally we saw how it really works". Pupils showed explicit interest in this type of experiment lesson, both with and without MBL. Implicitly, our introduced inquiry-based method motivated pupils; and they were surprised that they could learn from the notes they formulated during experiment observation and the following discussion. The engrossing combination of doing and understanding made them feel that they "took charge" of their own learning.

However, we noted less motivation to participate in the discussion from the more passive students. These were happy to just listen to the interchanges between the teacher and the 4-5 more active pupils. This can be explained in several ways. Firstly, our pupils 
were not used to lessons where they were expected to join in discussion with the teacher. Secondly, the teacher rarely asked the more passive pupils to discuss things, or the teacher had not initiated this interaction appropriately. Finally, the teacher may have fatigued pupils in his effort to engage as many of them as possible by repeating the differently formulated questions, and the overall effect of the teacher's endeavour to lead an interactive discussion may have became too complicated. We discuss this further under the "Pupil response to active engagement" heading.

The abovementioned constructive results confirm our expectation that this type of lesson has great potential to change pupils' attitude to science, and motivate more to study science.

\section{Pupil response in regard to concentration}

Our results clearly indicate that the teacher is more certain to maintain pupil concentration by interactive processes such as posing questions to pupils rather than by indulging in a monologue. This interaction helps pupils formulate their own ideas from the observed experiment.

It is also necessary to resolve how to place pupils to avoid them disturbing each other, and to ensure that everybody has a clear view of the experiment. However, it is preferable, whenever possible, to rearrange classroom seating before the lesson starts, so that pupils do not have to move at all.

It should also be decided if the apparatus and chemicals required in the experiment should initially be hidden, or if they should be in clear view of the students and subject to pupil discussion and distraction. In addition, it is advisable to distribute the worksheets with the interesting apparatus sketches at the previous lesson; to avoid distraction and thus enhance concentration on the experimental process.

In our lesson model, we chose a double demonstration of each experiment. We initially performed a demonstration without sensors, where pupils could just observe a studied phenomenon visible to the naked eye from a qualitative point of view. We then conducted the same demonstration using sensors. This approach worked really well, leaving no doubt that observation of a chemical reaction is perceived by pupils as a great experience. We noticed pupil enthusiasm and emotional expressions during the sensor-involved demonstrations of chemical reactions. We consider that if we had conducted experiments with the sensors first, pupils would not have paid so much attention to the quantitative observations recorded by data logging.

\section{Pupil response to active engagement}

Improved learning processes demand that formulated ideas are a product of the entire class or as many pupils as possible, and therefore the teacher should ask less-activated pupils to interpret their ideas and then compare comments with those of the more-involved students; thus engaging discussion. In our class, after engaging the most active pupils in discussion the teacher repeated the same question many times in different ways to encourage more students to interact. The teacher tried to avoid the following simple or rhetorical question requiring just "head-nodding" and no definitive answer: "Do you all agree with the answers the other pupils gave?" This would have suppressed engagement of the less-active pupils. However continued lack of participation can force the teacher to stop trying to involve those students, and be satisfied with answers from the most active ones. 
We cannot accept this outcome, and on no account should teachers resign themselves to this course, but they should pursue the interaction of as many pupils as possible

While we consider that asking the following simple question is better than formulating the same question in different ways, "What do you others say?", it is clearly better to combine both courses of action.

The low level of student participation in discussion is almost certainly due to their unfamiliarity with lessons expecting active involvement, and this appears the major reason for lower pupil engagement in the discussion process. This was evident with only 4-5 pupils actively participating in the first lesson and 5-6 in the second. It is advisable to occasionally request the pupils who always participate and exhibit above-average knowledge to refrain from answering so other pupils gain opportunities. Otherwise, less dominant students tend to completely withdraw from the discussion. Lack of familiarity in this type of lesson process may also be reflected in lower discipline and disturbances occurring during discussion when pupils should be concentrating on responding to teachers' questions and judging schoolmates' ideas. In early lessons of this type, some students may not consider answering questions to be tasks they should fulfil, and instead regard these lessons solely as interesting spectacles and magic in motion, and also as opportunities to relax as in free time rather than interact in the learning experience.

\section{Difficulties in implementing the lessons models}

In implementing our lesson models the teacher must solve two areas: using MBL and managing discussion in inquiry-based education. Our results highlighted that the area creating the most potential problems and therefore the most crucial area for successfully implementing MBL and inquiry-based lessons is good discussion management.

We experienced no difficulties using MBL, because we ensured that each teacher was appropriately prepared for this challenge, with all data-recording files for each lesson completed in advance. The following lesson-settings were recorded and saved; time and range of the experiment and the spatial representation of graphs and indicator values. Here, the apparatus and sensors had already been prepared and all measurements tested.

The fact that the experiments were teacher-demonstrated eliminated complications expected if pupil-groups conducted their own experiments. In this latter case, the teacher must set all MBL and other parameters to ensure students had the least actions to perform, and thus present the least problems possible. The pupils must be taught to use MBL and then strict supervision of MBL use in student-conducted experiments is required to prevent their misuse, and also to ensure students concentrate fully during class prediction and result discussions.

Certainly, the discussion is the most important part of the whole experimental process. The teacher must manage this discussion so that all students understand the experimental aims, processes and results. The teacher should (1) react appropriately to all pupils' expressed thoughts; (2) draw as many students as possible into active participation, the formulated ideas should reflect whole-class thinking; (3) this discussion should follow the prior-planned "discussion rules" as closely as possible. The success or failure of MBL inquiry-based experiments rest on the teacher's discussion expertise!

(1) The constructivist approach to education and inquiry-based learning springs from initial pupil ideas and concepts. Appropriate teacher reaction to expressed thoughts is paramount, because not only will discussion be impoverished if student input is not attended to, but the pupils involved can lose all interest in participating in discussion. 
In the part "Teacher response to pupil ideas", we can see what problems the teacher must solve and what situations present challenges in the discussion with pupils. The teacher must gain experience and be assiduous and patient, especially at first, and appropriate reaction to pupils' expressed ideas. The use of self-reflection and recording successful/failed aspects of initial lessons enable teachers to analyse and evaluate their lessons and alter their approach where necessary.

(2) Again, the teacher must engage as many students as possible, so that the formulated predictions and findings do not reflect only ideas of the most active pupils. Without active verbal participation in class discussion the teacher cannot verify if pupils attend to the discussion with internalised participation and understanding. This was fully discussed in the previous part "Pupils' responses in active engagement".

(3) Adhering to "discussion rules" is a further problem teachers face in this type of lesson; and here general class discipline is also involved, especially if pupils make fun of other students' ideas. This lesson type may also be considered an opportunity for free time by some pupils, with attention to discussion replaced by disruptive interaction spreading among inattentive students. These trends are controlled in the appropriate manner by the teacher; eliminating distraction of pupils' attention which can otherwise result in lack of understanding of subject matter, time-wasting, an unfavourable class atmosphere and pupil disinterest and tedium. The teacher must encourage pupils to adopt and maintain the rules and behaviour expected in these lessons throughout the entire school year.

All these problems can result from pupils being unused to teaching with continuous teacher/pupil communication. Therefore, teachers should use this style of teaching more often to prepare pupils for this beneficial approach. The pupil-oriented approach should be used regularly so students become used to it and understand that tasks must be done and rules followed; thus eliminating behavioural problems and class disruption. A similar principle is also involved in deciding the frequency of experiment-use in chemistry lessons. We suggest that teachers routinely include experiments in their lessons. When experiments are rarely incorporated, students don't perceive them as a standard part of lessons and they can be easily distracted.

\section{Changes in lesson model}

A very important constructivist principle is to motivate pupils so that the posed problem or question is so interesting for pupils that they make it their own. However, when our teacher first asked the task-solving question "Define what chemical reaction means", a lot of non-verbal pupil behaviour was noted. This included sighing, playing with pens, propping heads on hands and turning away from class activity. These reactions identified a level of disinterest in the task at hand. We consider this introduction too general and too abstract, and also a very likely reason so few pupils subsequently participated in the discussion.

The inductive approach in education and inquiry-based learning encourages us to substitute the following: "What will happen to the chemicals when we burn the ethanol?" This question is more concrete and should provide an easier answer for pupils, and it also facilitates the process of moving from a more concrete to more general approach.

Pupil disinterest and boredom can be provoked by a lot of writing. We need maintain the pupils' initial interest and motivation, therefore we should avoid to discouraging them by writing unnecessary answers and we also should find right time for writing necessary 
answers in their worksheets. In the case of our lesson models we recommend that pupils should enter the research question, experimental procedure and their observations in this order in their worksheets when the experiment and verbal formulation of the observation are concluded. We further recommend pupils do not write the predictions in their worksheets; the teacher writes them on the blackboard while maintaining verbal communication. Our video-recording verified loss of pupil attention and subsequent concentration on lesson-irrelevant issues when the teacher lost communication with pupils while making these blackboard annotations.

\section{Using the concept "to react"}

Under the Slovak national curriculum, pupils learn the term "Chemical Reaction" prior to obtaining any information about the particulate nature of matter; the atom and molecule particles. At the same time, the term "to react" is used in the chapter on chemical reactions in the chemistry textbook. Our experience with the use of this term confirms that pupils cannot properly understand this concept. Although discussion appeared more complicated when the teacher purposely used "to react", pupils should be allowed to use this term when they introduce it on their own initiative. In contrast, we do not recommend this term's inclusion in either the worksheets or in the definition of a chemical reaction. We consider pupils will easily understand this term when they are later taught the particulate nature of matter and chemical kinetics.

\section{Possible misunderstanding of "chemical decomposition" and "chemical synthesis" concepts}

When checking pupils' knowledge, we noted that pupils tended to differentiate the terms 'chemical decomposition' and 'chemical synthesis' from the term 'chemical reaction'. Some pupils correctly stated that chemical decomposition occurs when more products are formed from one reactant, and chemical synthesis is exactly the opposite. But they then stated that a chemical reaction is when two products are formed from two reactants. Therefore, it is necessary to stress that both chemical decomposition and chemical synthesis are also chemical reactions, and it is most important to show pupils more examples of chemical reactions with different numbers of reactants and products.

\section{Rules for appropriate implementation of inquiry and microcomputer-based lesson models}

Our final task was to establish "working-rules" the teacher should implement and follow to ensure successful model lessons. These were then trialled in practice chemistry classes as the next stage in the evaluation of our model-lesson suitability.

The only adjustments required in using MBL was that the teacher should always prepare all files needed for graph-recording and test all equipment function before each experiment class. No problems occurred in MBL usage when these changes were implemented and adhered to. Our suggested rules then concentrated entirely on the demonstration strategy and the inquiry-based learning components. Here, successful MBL use depends on the teacher mastering inquiry-based learning methodology and skilfully leading the discussion.

For successful model-lesson execution the teacher should explain lesson behaviour expected from pupils and encourage them to keep the rules during the whole school year, 
not only in these lessons. These ensure appropriate behaviour which becomes "second-nature"; and thus adhered to without thought. To achieve the best results, the teacher should:

- ensure well-structured class-room and student spatial organisation, and not have laboratory aids on view prior to the experiment

- $\quad$ have prepared files with the required settings for experimental data-recording

- create pupil worksheets so they had to write as little as possible, and distribute them at the end of the previous lesson to prevent distraction during MBL lessons

- $\quad$ not engage in monologues, but must lead the lesson expertly because all discussion is designed to activate pupils by posing appropriate questions

- $\quad$ engage all pupils by asking them to express their opinion to proffered ideas

- $\quad$ provide step-by-step assessment and feedback on each pupil's ideas

- $\quad$ lead discussion as simply as possible

- $\quad$ make the discussion as easy and clear as possible; straight-forward and not tedious

- $\quad$ avoid imposing teacher's ideas on pupils

- $\quad$ never belittle ideas expressed by pupils, and not allow classmates to mock each other's ideas

- $\quad$ ask pupils to formulate reasonable statements; pupils should not only guess

- use the inquiry-based method and experimentation routinely in lessons and emphasise the tasks that pupils are to solve

Pupils should also know and respect the basic rules of discussion:

- $\quad$ only one pupil can speak at any time

- when someone speaks, others listen to the stated opinion

- everybody can express themselves

- the discussion should not be disturbed by different activities or inappropriate remarks, and no opinion can be belittled or mocked

\section{Conclusions}

This work explores implementation of MBL and inquiry-based chemistry lesson models in Slovak Republic basic schools. Pupils have no experience with this type of education here, so we were particularly interested in how pupils and teachers would interact, the level of pupil cooperation with the teacher, what problems arose for both pupils and teachers and how these could be solved. We therefore created models on the topic "Chemical Reaction" using MBL and inquiry-based learning in primary schools and introduced them in school practice. We video-taped these lessons to collect relevant data and evaluated it with qualitative analysis.

The experience gained in the implementation-phase confirmed that effective teacher-pupil communication is the most complex issue facing teachers. This particularly concerns the formulation of predictions and conclusions which demands strong commitment, determination and skill from every teacher. The next requirement resulting from our work is to achieve pupil active engagement in the discussion. It is paramount to find an efficient way to encourage as many pupils as possible to participate in the discussion, and involvement of only the few most active pupils should not be considered satisfactory. A further teaching challenge was to achieve pupil rule-observation during the lesson, and particularly in the discussion. With few reservations, pupils managed this task and cooperated with the teacher. The lesson models required good planning and 
construction; and modifications gained from experience improved pupil motivation, maintained their interest in the topic and gained participation of as many pupils as possible. A set of working rules was created, and this included the teacher's ongoing evaluation of lessons and initiation of any changes required to ensure successful application of the models in our schools. This evaluation would also identify any issues which required further research and resolution.

The experience gained from constructing and testing our model lessons and from subsequent analysis of the video recordings proves that inquiry-based learning and MBL can be successfully included in primary education. While the appropriateness of this combined approach is established in previous research, our results prove that inquiry-based and MBL activities can be competently integrated in teacher demonstrations. Despite encountered difficulties, our lesson models are suitable for even the most basic terminology such as "chemical reaction" and they can easily be implemented in our education process.

Wider planned research is aimed at creating MBL and inquiry-based lesson models for additional school subjects with rules modified to suit specific teaching material. Finally, we consider that problems encountered in teacher/pupil communication in other lesson contexts should be addressed as we have done in our model lessons. Better communication in these areas will surely enhance pupil-oriented teaching methods.

\section{Acknowledgements}

This research has been made possible through grant APVV-0070-14.

\section{References}

[1] Thornton RK. Using the results of research in science education to improve science learning. In: Proc Int Conf Sci Educ. Nicosia, Cyprus; 1999. https://pdfs.semanticscholar.org/5e80/ e17d7cc3fc1f570fe53cd4eb41b721875ed7.pdf.

[2] Deng F, Chen W, Chai ChS, Qian Y. Constructivist-oriented data-logging activities in Chinese chemistry classroom. Asia-Pac Educ Res. 2011;20(2):207-221. https://ejournals.ph/article.php?id=4113.

[3] Tinker RF. Microcomputer-Based Labs: Educational Research and Standards. Heidelberg, Berlin: Springer; 1996. http://www.springer.com/us/book/9783642647406.

[4] Demkanin P, Bartosovic L, Velanova M. Simple multiplication as a form of presenting experience with introducing data loggers to physics teachers who do not have any experience with usage of such tools in education. In: Chova LG, Torres IC, Martinez AL, editors. EDULEARN12 Proc 4th Int Conf Educ New Learning Technol. Barcelona: IATED; 2012. http://www.ddp.fmph.uniba.sk/ bartosovic/papers/ Edulearn_2012.pdf.

[5] Tortosa $\mathbf{M}$. The use of microcomputer based laboratories in chemistry secondary education. Chem Educ Res Pract. 2012;13(3):161-171. DOI: 10.1039/C2RP00019A.

[6] Kennedy D, Finn S. The use of datalogging in teaching physics and chemistry in second-level schools in Ireland. Cork: The National Centre for Technology in Education, University College; 2000. http://citeseerx.ist.psu.edu/viewdoc/download?doi=10.1.1.117.2619\&rep=rep1\&type=pdf.

[7] Brasell $\mathrm{H}$. The effect of real-time graphing on learning graphic representations of distance and velocity. J Res Sci Teach. 1987;24(2):385-395. DOI: 10.1002/tea.3660240409.

[8] Beichner RJ. The effect of simultaneous motion presentation and graph generation in a kinematics lab. J Res Sci Teach. 1990;27(8):803-815. DOI: 10.1002/tea.3660270809.

[9] Seah WCh, Tan DKC, Hedberg JG, Koh TS. Use of dataloggers in science learning in Singapore schools. In: Looi Ch, Jonassen D, Ikeda M, editors. Proc 13th Int Conf Computers in Education. Singapore: ICCE; 2005. https://www.researchgate.net/publication/221319416_Use_of_Dataloggers_in_Science_ Learning_in_Singapore_Schools.

[10] Zucker AA, Tinker R, Staudt C, Mansfield A, Metcalf S. Learning science in grades 3-8 using probeware and computers. J Sci Educ Technol. 2008;17(1):42-48. DOI: 10.1007/s10956-007-9086-y. 
[11] Smejkal P, Stratilova Urvalkova E. Support for use of probeware in science for teachers and pupils. In: Ciesla P, Nodzynska M, Stawoska I, editors. Chemistry Education in the Light of the Research. Kraków: Pedagogical University of Krakow; 2012. http://comblab.eu/sites/default/files/publications/smejkal.pdf.

[12] Tan DKCh, Hedberg JG, Koh TS, Seah WCh. Datalogging: a unique affordance unrealized? In: ASERA 2005. Hamilton: Australasian Science Education Research Association; 2005. https://repository.nie.edu.sg/ bitstream/10497/2737/1/datalogging_ASERA.pdf.

[13] Sorgo A, Kocijancic S. False reality or hidden messages: Reading graphs obtained in computerized biological experiments. Eurasia J Math Sci T. 2012;8(2):129-135. DOI: 10.12973/eurasia.2012.826a.

[14] Bingimlas KA. Barriers to the successful integration of ICT in teaching and learning environments. Eurasia J Math Sci T. 2009;5(3):235-245. DOI: 10.12973/ejmste/75275.

[15] Corbin J, Strauss A. Basics of Qualitative Research: Techniques and Procedures for Developing Grounded Theory. Thousand Oaks: SAGE Publications; 2007. DOI: 10.4135/9781452230153.

[16] Banchi H, Bell R. The many levels of inquiry. Sci Children. 2008;46(2):26-29. https://engage.intel.com/ servlet/JiveServlet/previewBody/30979-102-1-37824/4\%20Levels\%20of\%20Science\%20Inquiry.pdf.

\title{
W JAKI SPOSÓB UCZNIOWIE MOGĄ ZOBACZYĆ TO, CO JEST NIEWIDZIALNE?: MOŻLIWOŚCI DOCIEKANIA PODCZAS REALIZACJI EKSPERYMENTU W SZKOŁACH PODSTAWOWYCH
}

\begin{abstract}
Abstrakt: Przeanalizowano trudności i wyzwania dla nauczycieli w zakresie wdrażania mikrokomputerowego laboratorium i edukacji opartej na dociekaniu w szkołach podstawowych, w których uczniowie nie byli poddawani tego rodzaju edukacji. Aby to osiągnąć, wdrożono modele lekcji z arkuszami roboczymi poświęconymi reakcjom chemicznym analizy i syntezy; z pokazami doświadczeń i utrwalaniem każdej lekcji na wideo. Nagrania te zostały przeanalizowane jakościowo, koncentrując się na okolicznościach prowadzących do zwiększenia lub zmniejszenia uwagi uczniów na odpowiednich wydarzeniach, oraz pozwoliły na sformułowanie późniejszych wniosków. Doświadczenia zdobyte podczas wdrażania lekcji modelowych dowiodły, że osiągnięcie skutecznej komunikacji nauczyciel-uczeń było największą trudnością ograniczającą sukces nauczania. W szczególności dotyczyło to formułowania przewidywań i wniosków, które wymagają od każdego nauczyciela silnego zaangażowania, determinacji i umiejętności. Kolejną trudnością było zapewnienie aktywnego zaangażowania uczniów w dyskusję. Dlatego został stworzony zestaw „zasad pracy” nauczycieli, aby zwiększyć sukces w tej innowacyjnej formie edukacji.
\end{abstract}

Słowa kluczowe: reakcja chemiczna, doświadczenie pokazowe, edukacja naukowa oparta na dociekaniach, laboratorium mikrokomputerowe, arkusze robocze 